\title{
THE CLINICAL DIVIDE: OVERCOMING BARRIERS TO COLLABORATION BETWEEN CLINICS AND LEGAL WRITING PROGRAMS*
}

\begin{abstract}
Increased communication between legal research and writing ("LRW") programs and clinical programs is desirable because it provides students with a seamless learning experience, enhances faculty teaching in both departments, and creates opportunities for collaboration that benefits a law-school community generally. But barriers presently exist that hinder collaboration. Specifically, barriers that impact collaboration and integrated learning between LRW and clinical programs stem from: (1) differences in the development of the two disciplines and the resultant differences in teaching methodologies; and (2) other practical barriers including physical separation, status issues, lack of communication, competing demands within the law school and the reality of how little collaboration presently occurs. With respect to the first barrier, which is the most deeply rooted and the most salient, the differences in the development of clinics versus LRW programs has created, on the clinical side an approach to teaching that is defined by progressive, client-centered and reflective learning and on the LRW side teaching methodologies guided by traditional, lawyer-centered, and forward-looking principles. Because these approaches are so different and because in practice clinicians and LRW faculty are not regularly communicating on these issues, faculty cannot provide seamless instruction to students. But clinical and LRW faculty can overcome these differences with increased communication and a conscientious commitment to incorporate principles of each other's teaching into their own pedagogy. The author encountered and addressed these very difficulties in the context of designing a hybrid LRW-clinical course at Northwestern University School of Law.
\end{abstract}

\section{TABLE OF CONTENTS}

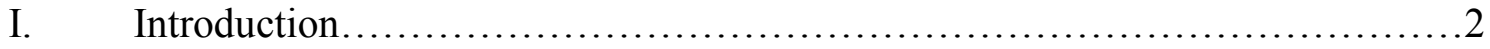

II. Barriers Resulting from the Development of the LRW and Clinical Disciplines and the Teaching Methodologies.............................................

A. Development of Clinical Programs $\ldots \ldots \ldots \ldots \ldots \ldots \ldots \ldots \ldots \ldots \ldots \ldots \ldots$

B. Development of LRW Programs.................................... 14

III. Other Practical and Perceived Barriers......................................24

IV. Overcoming the Barriers.............................................29

* C Sarah O’Rourke Schrup 2006. Clinical Assistant Professor, Northwestern University School of Law. B. S. Georgetown University, J.D. University of Michigan. Special thanks to Abby Mollen for her outstanding research assistance, to my colleague Susan Provenzano for her insightful comments, and to my husband and daughter for their support. 
V. Crossing the "Clinical Divide": One Teacher's Attempt to Bridge the Gap.....33

A. The Preliminary Design....................................... 33

B. The Revised Design............................................ 36

VI. Conclusion.........................................................41

I. Introduction

Increasing focus has been directed at the incidence and importance of

collaboration across law school programs and, in particular, between legal research and writing (LRW) programs and clinical programs. ${ }^{1}$ Part of the increased scrutiny stems from a mutual dissatisfaction with student performance and experience from the end of the first year and into the final two. That is, even when LRW faculty members believe they have produced within each student the best writer that student can be in his nascent legal career, upper-level faculty, including clinicians, lament the research and writing

${ }^{1}$ See generally Michael A. Millemann \& Steven D. Schwinn, Teaching Legal Research and Writing with Actual Legal Work: Extending Clinical Education Into the First Year, 12 CLINICAL L. REV. 441 (2006) (concluding that LRW and clinical faculty should collaborate to introduce actual legal work in firstyear writing courses); Angela J. Campbell, Teaching Advanced Legal Writing in a Law School Clinic, 24 SetOn HaLl L. ReV. 653, 663 (1993) (concluding that law schools can improve students' writing by offering clinical opportunities that teach advanced legal writing); Pamela Lysaght \& Cristina D. Lockwood, Writing-Across-the-Law-School Curriculum: Theoretical Justifications, Curricular Implications, 2 J. FOR ASS'N LEGAL WRITING DIRECTORS 73, 73-74 (2004) (noting that the "burden of teaching 'good legal writing' ... must be shared within the wider law school community"). Lysaght and Lockwood further note that four themes emerge from dominant learning theory that ultimately support the goal of seamless integration of writing instruction during law school: (1) "instruction should begin at a point within a student's current understanding, requiring that teachers start with the basics within a subject"; (2) "students should be exposed to a variety of teaching methods"; (3) "students should apply what they are learning and receive feedback"; and (4) "students should be taught to be autonomous learners." Id . at 90-92. The authors conclude that a program where law students "write across the curriculum" in doctrinal and clinical courses would offer students the necessary depth and breadth of legal writing instruction. Id. at 99-100. See also Laurel Currie Oates, $I$ Know That I Taught Them How to Do That, 7 Legal Writing: J. Legal Writing Inst. 1, 1 (2001) (noting that "[f]or years teachers have complained that students are not able to recognize that information acquired in one class is also applicable in another class"). 
skills of the students that enter their courses. ${ }^{2}$ And, on the other side of the coin, LRW

faculty members generally believe that students' newly-acquired skills atrophy without

practice and consistent reinforcement in different contexts throughout the remainder of

law school. ${ }^{3}$ And although scholars are just beginning to assess the actual collaboration

that presently is occurring within law schools nationwide, ${ }^{4}$ as discussed below value

accrues to students, clinics, legal writing programs, and law schools generally when

increased coordination and seamless integration of the learning process occur.

Turning first to the benefits for law students, collaboration between clinics and

LRW departments furthers the goals of the MacCrate Report, which since its publication

${ }^{2}$ Lysaght \& Lockwood, supra note 1, at 73 (citing a recent study assessing the writing skills of new lawyers published in the Journal of Legal Education that concluded "most lawyers, including most new lawyers, do not write well"); Teresa Godwin Phelps, The New Legal Rhetoric, 40 Sw. L.J. 1089, 1098 (1986) ("Although many in the legal profession see legal writing courses as remedial, teachers of advanced writers generally concur that first-year law students possess 'flat competence,' which is the ability to produce .... a document not marred by mistakes of spelling or grammar. Nonetheless, their writing lacks an authentic voice." (quoting Maxine Hairston, Working with Advanced Writers, $35 \mathrm{C}$. COMPOSITION AND COMM. 196, 198 (1984))).

${ }^{3}$ Lysaght \& Lockwood, supra note 1, at 74-75 (noting that students' shortcomings as legal writers result, in part, from the absence of opportunities to apply legal writing skills developed in first-year writing courses in the following years); J. Christopher Rideout \& Jill J. Ramsfield, Legal Writing: A Revised View, 69 WASH. L. REV. 35, 75-76 (1994) (noting that "if legal educators under the formalist view assume that one year is enough time to become proficient in the new discourse, they abandon students just as acculturation begins" and advocating a program that allows students to reinforce and develop writing skills steadily throughout the last two years of law school). One proffered solution is to bridge the gap between first-year LRW classes and the upper-level courses, both clinical and doctrinal. See, e.g., Lysaght \& Lockwood, supra note 1, at 73-74 (2004) (advocating adoption of writing across the curriculum programs). On the clinical side, some have focused on integrating clinical experiences into the first-year legal research and writing programs, see, e.g., Millemann \& Schwinn, supra note 1, while others have advocated for clinics as a vehicle for advanced writing training, see, e.g., Campbell, supra note 1, at 658-62 (concluding that clinics present richer and ultimately more successful learning opportunities for students than classroom or simulated writing experiences); Maureen E. Laflin, Toward the Making of Good Lawyers: How an Appellate Clinic Satisfies the Professional Objectives of the MacCrate Report, 33 Gonz. L. REV. 1, 33-38 (1998) (exploring how clinical education promotes advanced writing skills).

${ }^{4}$ In 2005 the Legal Writing Institute's Legal Writing, Clinical and Pro Bono Committee surveyed clinicians and legal writing professionals to assess the level of collaboration between departments. The survey results are discussed in Part III infra. 
in 1992 by a special ABA Task Force on Law Schools and the Profession, has set the

benchmark for legal education. ${ }^{5}$ The MacCrate Report sets forth core skills and values in a Statement of Fundamental Lawyering Skills and Professional Values. ${ }^{6}$ Both LRW

scholars and clinical scholars have addressed how their programs individually satisfy the

mandates of the MacCrate Report. ${ }^{7}$ If each program standing alone furthers the

MacCrate report's goals, then it logically follows that increased cooperation among

departments also would enhance law-school learning in the ways envisioned by the

MacCrate Report. ${ }^{8}$ And, aside from satisfying the MacCrate Report's specific goals, collaboration provides other learning benefits to students. When clinicians and LRW

faculty members share their methodologies and adopt in part each other's approaches,

they provide context, continuity and reinforcement of the principles taught in each

5 See Section of Legal Educ. \& Admissions to the Bar, ABA, Legal EdUCATION AND Professional DEVELOPMENT -- AN EDUCATIONAL CONTINUUM, REPORT OF THE TASK FORCE ON LAW SCHOOLS AND THE PROFESSION: NARROWING THE GAP (1992), available at http://www.abanet.org/legaled/ publications/onlinepubs/maccrate.html [hereinafter MACCRATE REPORT].

${ }^{6}$ The MacCrate Report addresses ten essential lawyering skills: “(1) problem solving; (2) legal analysis and reasoning; (3) legal research; (4) factual investigation; (5) communication (oral and written); (6) counseling; (7) negotiation; (8) litigation and alternative dispute resolution procedures; (9) organization and management of legal work; and (10) recognizing and resolving ethical dilemmas." Laflin, supra note 3, at 4-5 (suggesting that clinical curricula may be tailored to promote the objectives of the MacCrate Report). The MacCrate Report also identifies four ideals that represent the moral foundation of legal practice and to which each lawyer should aspire: "(1) providing competent representation to clients; (2) promoting justice, fairness, and morality within society; (3) maintaining and improving the legal profession; and (4) developing professionally as a lawyer." Id.

7 See, e.g., Debra Harris \& Susan D. Susman, Toward a More Perfect Union: Using Lawyering Pedagogy to Enhance Legal Writing Courses, 49 J. Legal EdUC. 185 (1999) (LRW); Mary Beth Beazley, Better Writing, Better Thinking: Using Legal Writing Pedagogy in the "Casebook" Classroom (Without Grading Papers), 10 LEGAL Writing: J. LeGAL WRITING INST. 23 (2004) (same); Angela McCaffrey, Hamline University School of Law Clinics: Teaching Students to Become Ethical and Competent Lawyers for Twenty-Five Years, 24 HAMLINE J. PUB. L. \& POL'Y 1 (2002) (clinical education); Ann Juergens, Using the MacCrate Report to Strengthen Live-Client Clinics, 1 CLINICAL L. REV. 411 (1994) (same). One scholar has explicitly concluded that an advanced appellate advocacy clinic, which combines clinical and LRW teaching, satisfies each of the three broad categories of skills outlined in the MacCrate Report--analytical skills, practical skills, and ethical skills--while simultaneously reinforcing the four core values. Laflin, supra note 3, at 8.

${ }^{8}$ See supra notes $1-3$ and accompanying text. 
course. Students further learn that there is broader relevance to the tenets introduced in first-year LRW when they apply them, as learned, in a clinical setting and students are better able to direct their efforts in the clinics when those professors use similar terminology and approaches. Finally, there is less danger of contradiction and confusion when faculty members have agreed to create a cooperative approach across courses. Put simply, providing continuity for students enhances learning 9 and permits them to better internalize the skills and values of the MacCrate Report.

Benefits from collaboration between LRW departments and clinics also impact faculty and law schools as a whole. ${ }^{10}$ Increased communication between LRW and clinical faculty could result in new teaching opportunities, collaborative scholarship, or other projects. Improved bonds between the departments could unearth similar pay and status issues within each department that could then be presented jointly to the lawschool administration. Clinicians will benefit from better-prepared students and both LRW and clinical faculty members could improve their teaching by incorporating the best approaches of each other's methodologies. The strengths that define each discipline, such as LRW's focus on composition theory and cognitive psychology and the clinics' overriding social-justice commitments, ultimately could be furthered as a result of improved bonds. Finally, law schools as a whole benefit by providing the unique,

\section{See id.}

10 The importance of collaboration was the topic at the recent 2006 AALS Conference on Clinical Legal Education. In fact, at the conference one session was devoted to "Collaboration Across Law School Programs" and specifically discussed "the rewards and challenges of collaboration between clinics and legal writing programs." See Sarah E. Ricks \& Susan C. Wawrose, et al., Handout for "Collaboration Across Law School Programs" presented at AALS Conference on Clinical Legal Education (May 1, 2006) (on file with author and hereinafter "AALS Handout"). 
cutting-edge programs that emerge from new collaborative arrangements and by creating better-prepared students who fulfill the mandates of the MacCrate Report.

If collaboration is a good idea, why is it not more prevalent? As discussed below, presently the very strengths within each program can themselves serve as barriers to collaboration between them and can ultimately hinder seamless learning from the firstyear program into advanced, clinical-based writing. The most fundamental barrier to collaboration and integrated learning between LRW programs and clinical programs stems from differences in the development of the two disciplines and the resultant differences in teaching approaches. These differences are defined on the clinical side by a progressive or "rebellious" approach to lawyering that is at odds with the more traditional or "regnant" approach to lawyering that is adopted in many first-year LRW classes. ${ }^{11}$ In addition, collaboration is impacted by other practical barriers including physical separation, status issues, lack of communication, competing demands within the law school, and the reality of how little collaboration presently occurs. These barriers became particularly acute for me as I attempted to create from the ground up a new clinical offering at Northwestern that was specifically designed to incorporate aspects of both camps: a clinical course with specific, intensive focus on writing. This article explores my effort to acknowledge and attack these real and perceived barriers in a conscientious way so as to minimize their impact and ultimately produce the seamless

11 John O. Calmore, A Call to Context: The Professional Challenges of Cause Lawyering at the Intersection of Race, Space, and Poverty, 67 FoRDHAM L. REV. 1927, 1933-34 (1999) (describing two models of providing legal services to the poor, originally described by Gerald López as "regnant" and "rebellious" lawyering: "[R]egnant lawyers tend to maintain a disassociated power over their clients, embracing the traditional lawyer-client paradigm. By contrast, "the rebellious idea of lawyering demands that lawyers (and those with whom they work) nurture sensibilities and skills compatible with a collective fight for social change."'). 
law-school learning experience that would most benefit my students and their development as legal writers.

This article begins with the proposition that collaboration between clinics and LRW programs is important to create additional vehicles for students to hone and advance their legal research and writing skills in a real-life context. The article first describes the development of clinical and legal writing programs, respectively, and assesses potential crossover barriers resulting from the differences between the development of these respective disciplines and the resultant approaches to teaching. Next, the article reviews additional barriers to successful collaboration that stem from practical differences between clinical and LRW departments. Third, the article offers suggested solutions for bridging these gaps. Finally, the article concludes by examining these concepts in practice, and how these barriers were acknowledged and addressed in the context of the development of an advanced legal-writing clinic at Northwestern Law School.

II. Barriers Resulting from the Development of LRW and Clinical Disciplines and the Teaching Methodologies

One central way in which the goal of seamless collaboration between LRW and clinical programs has been undermined is through the barriers set forth by the structural development of each discipline and the resulting focus of each in teaching and scholarship. Specifically, the development of law-school clinics ultimately resulted in teaching methodologies that encapsulate their "rebellious," public-interest and socialjustice origins and commitment to experiential, reflective, and organic learning. LRW programs, on the other hand, which in recent history are guided by learning, discourse 
and composition theory, teach students prescriptively to write to an audience with specific expectations regarding form, style, structure and voice, which often results in the "regnant" approach to lawyering discussed above. Examining the historical development of the programs, their goals, and their teaching methodologies and scholarship shows that there are fundamental pedagogical differences between the disciplines that impact the ability of students to seamlessly integrate learning from each and that inhibit the communication and collaboration between departments that could ease such a transition.

\section{A. Development of Clinical Programs}

Clinical education in law schools grew out of the apprenticeship model of lawyer training, which was the norm until the early twentieth century. ${ }^{12}$ As apprenticeship declined, legal education in law schools supplanted it. ${ }^{13}$ Clinics as we know them developed out of the legal realist movement in the 1930s, which "taught that legal education should expose students to the dynamic relationship between theory and practice." 14 A second wave of clinical growth occurred in the 1960s and 1970s due to widespread student demand and increased financial support from private foundations, which stemmed from heightened social unrest, activism and the recognition of socialjustice concerns in legal education. ${ }^{15}$ In the late 1960s, William Pincus, a Ford Foundation officer, persuaded the Ford Foundation to establish the Council on Legal

\footnotetext{
12 William P. Quigley, Introduction to Clinical Teaching for the New Clinical Law Professor: A View from the First Floor, 28 AKRON L. REV. 463, 466 (1995).

${ }^{13} I d$.

14 Stephen Wizner, The Law School Clinic: Legal Education in the Interests of Justice, 70 FORDHAM L. REV. 1929, 1932 (2002).

15 Jon C. Dubin, Clinical Design for Social Justice Imperatives, 51 SMU L. REV. 1461, 1465 (1998).
} 
Education for Professional Responsibility, a separate foundation under Pincus's

leadership that would provide grants to law schools to establish legal clinics assisting the economically disadvantaged. ${ }^{16}$ Within several years, clinical legal education had a foothold in most American law schools. ${ }^{17}$ Although clinical faculty hailed from a variety of backgrounds, ${ }^{18}$ former careers in various forms of poverty law or other public-interest organizations often were launching points for clinical faculty careers. ${ }^{19}$

Originally, the primary goal in many law school clinics was to provide service to their disadvantaged clients, but this goal was supplemented by educational goals over time. ${ }^{20}$ Thus, in the wake of the MacCrate Report's call for more professional skill training in American law schools, clinics increasingly focused on pedagogical goals, including skills training, in addition to their legal-aid and public-service concerns. ${ }^{21}$

16 Wizner, supra note 14, at 1933. Northwestern's clinical education era began in 1967-68 with just such a grant from CLEPR. See Thomas F. Geraghty, Legal Clinics and the Better Trained Lawyer (Redux): $A$ History of Clinical Education at Northwestern, 100 Nw. U. L. REV. 231, 240 (2006).

17 Wizner, supra note 14, at 1933; see also Dubin, supra note 15, at 1463-64 (noting that, even prior to existence of CLEPR funding, by the late 1950s about twenty-five law schools offered programs based on a legal aid clinic model).

18 Justine A. Dunlap \& Peter A. Joy, Reflection-in-Action: Designing New Clinical Teacher Training by Using Lessons Learned from New Clinicians, 11 CLINICAL L. REV. 49, 50 (2004) (noting that clinical faculty come from a variety of legal backgrounds including legal services and other nonprofit legal practice, government practice and private law firms).

19 James E. Moliterno, In-House Live-Client Clinical Programs: Some Ethical Issues, 67 FoRDHAM L. REV. 2377, 2387 (1999).

20 Philip G. Schrag, Constructing a Clinic, 3 CLINICAL L. REV. 175, 180 n.17 (1996) (citing Minna J. Kotkin, Reconsidering Role Assumption in Clinical Education, 19 N.M. L. REV. 185, 192 (1989)).

21 Dubin, supra note 15, at 1469-70 (noting, however, that social justice dimensions, have not been supplanted by this new focus on education, since present-day clinics provide "fertile laboratories" for the academy to explore its "heightened [] interest in conceptions of client and community empowerment and on transforming the social consciousness of law students by deconstructing power and privilege in law" that has come with the emergence of schools of critical legal thought). But $c f$. Frank S. Bloch, The Andragogical Basis of Clinical Legal Education, 35 VAND. L. REV. 321, 350-51 
Social-justice considerations and progressive lawyering still played important

pedagogical goals, though, given the clinics' long-standing commitment to public service and the MacCrate Report's specific call for law school education that reflects and instills the profession's “justice, fairness, and morality" goals. ${ }^{22}$ Today's clinical programs are constructed to satisfy a variety of goals, most of which are student-centered:

- to teach students to accept and assume responsibility for important matters

- to teach students about a new area of law

- to provide free legal services to people in need

- to improve students' problem-solving abilities

- to teach collaboration

- to create cross-cultural awareness

- to cue students to the emotional aspects of being a lawyer

- to teach students how to effectively deal with facts

- to create opportunities for students to think about their own social values

- to encourage students to struggle with ethical issues

- to enhance students' creativity

- to teach students to exercise authority

- to create opportunities for students to become aware of their learning styles

(1982) (suggesting that clinical case selection should be based on the extent cases maximize educational value to the students rather than their potential to serve social justice goals).

22 Dubin, supra note 15 , at 1464-65, 1473. Other scholars have noted that a social-justice perspective must be at a clinic's structural core for it to succeed in its educational goals. See, e.g., Bernard K, Freamon, A Blueprint for a Center for Social Justice, 22 SETON HALL L. REV. 1225, 1230 (1992) ("Any law school clinic that myopically defines its educational mission as simply 'skills development' .... without explicitly identifying the larger, more philosophic goal of improving the quality of justice in American society will have little success in preparing its graduates for a rewarding and satisfying career in the practice of law in the twenty-first century."). 
- to teach students traditional lawyering skills through practice, supervision and personal feedback. ${ }^{23}$

The way clinics developed, the nature of live-client clinical practice, and the above-stated goals of clinical education can be distilled into one overarching concern that influences the teaching methodologies adopted in a clinic: resolving the tension between the educational duty to teach the student and the ethical duty to serve the client. ${ }^{24}$ The ethical duty of representation results in teaching a "client-centered" approach to lawyering. ${ }^{25}$ The educational goals are best served by creating an environment that permits learning via experience and reflection, which is best suited to adult learning styles and which means providing feedback without undue intervention and directiveness. ${ }^{26}$ Clinicians have found these dual methodologies compatible and effective in addressing the competing duties by providing for the client's interests while simultaneously incorporating adult learning styles.

Turning first to the concept of client-centered lawyering, one unifying feature of clinical practice is that it seeks to teach students to "empower clients to make important decisions at each step of the legal process." 27 The client is given autonomy over the case,

\footnotetext{
${ }^{23}$ Schrag, supra note 20, at 179-185; see also Quigley, supra note 12, at 472-73 (outlining nine, similarly student-centered goals of clinical education as stated by the AALS Committee on the Future of the InHouse Clinic).

${ }^{24}$ See Dunlap \& Joy, supra note 18 , at 88.

${ }^{25}$ George Critchlow, Professional Responsibility, Student Practice, and the Clinical Teacher's Duty to Intervene, 26 GONZ. L. REV. 415 (1991).

${ }^{26}$ See Dunlap \& Joy, supra note 18 , at 89-90.

${ }^{27}$ Keri K. Gould \& Michael L. Perlin, "Johnny's in the Basement/Mixing Up His Medicine”: Therapeutic Jurisprudence and Clinical Teaching, 24 SEATtLE U. L. REV. 339, 352 (2000) (footnote omitted).
} 
while the lawyer concomitantly relinquishes control and instead focuses on teaching the student to help the client make decisions that are consistent with the client's values. ${ }^{28}$ Client-centered lawyering thus proposes "a relationship that is more egalitarian than is found within the traditional power structure of a paternalistic attorney-client relationship." 29 These tenets are tied to the ideal of "rebellious" lawyering, which seeks to empower subordinated clients. ${ }^{30}$ Rebellious lawyering is defined by consciously disavowing lawyer-client relationships that disempower the client, investigating novel, even non-legal, approaches to problem solving, and actively collaborating with the client and community professionals to effect social change. ${ }^{31}$ The combination of clientcentered, rebellious lawyering in clinical legal education along with the resurgence of social-justice concerns in clinics, both of which places the client and lawyer together in the decision-making process, has become the pedagogy of choice for many clinicians because it effectively satisfies both their educational missions as well as their ethical duty of representation for their clients. ${ }^{32}$

28 Elliott S. Milstein, Clinical Legal Education in the United States: In-House Clinics, Externships, and Simulations, 51 J. LEGAL EDUC. 375, 378 (2001).

${ }^{29}$ Gould \& Perlin, supra note 27, at 352.

${ }^{30}$ Gerald P. López, Reconceiving Civil Rights Practice: Seven Weeks in the Life of a Rebellious Collaboration, 77 GEO. L. J. 1603, 1608 (1989) (defining "rebellious lawyering" as a collaborative problem-solving process between lawyer, client and community aimed at achieving "social change").

${ }^{31} I d$.

32 See Dubin, supra note 15, at 1470-74 (noting a recent "resurgence in focus on [] social justice dimensions" in clinical education based on the emergence of critical lawyering theory, the MacCrate Report's emphasis on instructing students in the law's justice, fairness, and morality values, the growing pro bono movement, the new sources of clinical funding that have emphasized the "access to justice" goals of clinical education by imposing "various indigent service obligations on funded programs," and the recent creation or modification of several clinical programs with "unapologetically paramount social justice goals"); López, supra note 30, at 1608.. 
The concept of experiential learning is the other anchor of clinical legal education. ${ }^{33}$ Building on adult learning theory, which emphasizes "bolstering the learners' ability to be a self-directed learner in the future through opportunities for reflection on the lessons gained through experience," clinical education has been called the "ideal adult learning environment" when accompanied by opportunity for reflection. ${ }^{34}$

That is, during the "disorienting moment" when a person encounters an unsettling experience and grapples with it, optimal learning occurs. ${ }^{35}$ During these moments, the learner engages in critical thinking and reassesses her own personal beliefs and values. ${ }^{36}$ In the clinical legal setting experiential learning often readjusts the students' notions of justice. By observing the impact of the legal system on their clients and by working within that system students learn not only the meaning of justice within that system but also develop their own concept of justice from that experience. ${ }^{37}$ Relying on experiential learning impacts the clinician's approach to teaching and supervision. ${ }^{38}$ The clinician's

33 See Dunlap \& Joy, supra note 18, at 52 ("[T] he primary goal of clinical legal education is to teach students how to learn from experience."); Quigley, supra note 12, at 474 ("Clinical education, at its essence, is a process of learning how to learn from experience."); see also Dubin, supra note 15, at 1477 (noting that clinical education's experiential nature supports its larger social justice goals "by facilitating [students'] transformative experiential opportunities for exploring the meaning of justice and developing a personal sense of justice through exposure to the impact of the legal system on subordinated persons and groups and through the deconstruction of power and privilege in the law" (footnotes omitted)).

34 Fran Quigley, Seizing the Disorienting Moment: Adult Learning Theory and the Teaching of Social Justice in Law School Clinics, 2 CLINICAL L. REv. 37, 50 (1995); see also Dunlap \& Joy, supra note 18, at 51-52 (noting that clinical teaching methodology "relies upon faculty starting with the explicit premise that the experiences of law students ... become the 'text' for the students' continuing education in law" and to teach them to be reflective practitioners).

${ }^{35}$ Quigley, supra note 34, at 51.

${ }^{36} I d$. at 52 .

${ }^{37}$ Dubin, supra note 15, at 1477.

${ }^{38}$ Bloch, supra note 21, at 348-50. 
role is to facilitate these "disorienting moments" and to provide opportunities for reflection and the shift in perspective that accompanies the experience. ${ }^{39}$ In both teaching and supervision, the goal is to allow students to direct their own learning without excessive intervention and directiveness. ${ }^{40}$

Clinicians' scholarship mirrors their dualistic role as practitioners and teachers, by exploring, among other things, not only "adult learning styles, clinical teaching methodology, and theories of lawyering and legal practice, ${ }^{\prime 41}$ but also the central role of "narrative voice" or "critical lawyering" in clinical legal education, which incorporates the ideals of the progressive or "rebellious" approaches. ${ }^{42}$ This combination of progressive lawyering, a commitment to reflective, experiential learning, and overriding public-interest and social-justice concerns, all of which emerged through the development of the clinical discipline, has created a learning environment that differs from that in other law school courses, both doctrinal and in LRW.

\section{B. Development of LRW Programs}

Like clinical programs, innovations in the teaching of writing appeared early in the twentieth century but LRW did not fully come into its own as a discipline until much

\footnotetext{
39 Quigley, supra note 34, at 55.

${ }^{40}$ Bloch, supra note 21, at 348-50 ("[T]he student should help the teacher decide when the teacher needs to direct and teach, and when the student can be left alone").

${ }^{41}$ Gould \& Perlin, supra note 27, at 350-51 (footnotes omitted) (arguing generally that therapeutic jurisprudence (focusing on client and outcome most therapeutic to client) in clinical teaching creates in students an affinity for engaging in multidisciplinary investigation and evaluating the therapeutic effects of the lawyering process or the case disposition).

42 Id. at 351-52.
} 
later. The value of teaching students about legal research and writing was first recognized in the early 1900s, and "legal bibliography" courses, which described the sources of legal authority and the mechanics of legal research, ${ }^{43}$ were the primary vehicle for basic legal-writing instruction. ${ }^{44}$ Formalized LRW programs in various forms sprouted up during the 1940s and 1950s. ${ }^{45}$ However, for the most part, legal writing courses from the 1950s to the 1970s remained "marginal and peripheral." twenty-five years, however, the LRW field has expanded so that today every accredited law school offers some form of LRW instruction. ${ }^{47}$ Along with this growing discipline is an impressive body of scholarship about $\mathrm{LRW}^{48}$ and a cadre of professionals who are committed to teaching writing, and only writing, as an independent discipline. ${ }^{49}$

43 David S. Romantz, The Truth About Cats And Dogs: Legal Writing Courses and the Law School Curriculum, 52 U. KAN. L. REV. 105, 128 (2003).

${ }^{44}$ Emily Grant, Toward a Deeper Understanding of Legal Research and Writing as a Developing Profession, 27 VT. L. REV. 371, 375-76 (2003) (citing Alfred F. Mason, Brief-Making in Law Schools, 1 AM. L. SCH. REV. 294, 294 (1905)).

$45 I d$. at 375-76 (identifying various law schools pioneering LRW programs during this period, including Northwestern).

${ }^{46}$ Romantz, supra note 43 , at 133 . Romantz notes that at least four factors contributed to this marginalization: (1) LRW courses seemed contrary to the Langdellian case-method approach because they failed to incorporate inductive learning; (2) LRW courses arose in the wake of the legal realist movement and thus were considered skills courses; (3) LRW courses developed in the post-WWII era, partially to correct grammar and composition inadequacies of these students and thus were viewed as remedial; and (4) LRW courses were expensive and labor-intensive and thus inefficient. Id.

${ }^{47}$ Grant, supra note 44 , at 377.

${ }^{48}$ Id. at 376-377 (citing Jan M. Levine, Voices in the Wilderness: Tenured and Tenure-Track Directors and Teachers in Legal Research and Writing Programs, 45 J. LEgAL EDUC. 530, 531 (1995)); see also Michael R. Smith, Rhetoric Theory and Legal Writing: An Annotated Bibliography, 3 J. FOR Ass'N LEGAL WRITING DIRECTORS 129, 129 (2006) (setting forth bibliography of articles on rhetoric theory and legal writing).

49 Jo Anne Durako, A Snapshot of Legal Writing Programs at the Millennium, 6 LEGAL WrITING: J. LEGAL WRITING INST. 95, 100 (2000) (noting that based on a 1999 survey, "it is now safe to say that the writing field is populated by professionals drawn to teaching writing"). 
Building on New Rhetoric theory, cognitive psychology and learning theory, LRW faculty have created scholarship and an approach to teaching that is based on, among other things, the following three tenets: (1) composition theory that is process-based and reader-based; (2) notions of discourse communities and the transfer problems inherent in this construct; and (3) expert-novice gaps in learning. ${ }^{50}$ As discussed below, however, each of these guiding principles reinforces a traditional, top-down "regnant" approach to lawyering that is at odds with clinical methodologies.

Briefly examining the underpinnings of these guiding theories sheds light on teaching approaches employed by LRW faculty members. At the outset it is important to understand the context in which first-year LRW faculty members teach in order to understand why some of the teaching methodologies are employed. LRW professors are charged with the daunting task of corralling the writing styles and abilities of, on average, forty-four first-year students into an acceptable baseline of legal writing competency. ${ }^{51}$ Thus, unlike clinical courses, which often average no more than ten students, LRW faculty members must, to some extent, employ baseline structures and paradigms in their teaching to ensure that their teaching encompasses not only the varied writing styles and backgrounds, but also the differences in skill among their students. Within this context, LRW faculty members have incorporated fundamentals from New Rhetoric theory,

${ }^{50}$ Lisa Eichhorn, The Legal Writing Relay: Preparing Supervising Attorneys to Pick Up the Pedagogical Baton, 5 Legal Writing: J. Legal Writing INST. 143, 150-54 (1999).

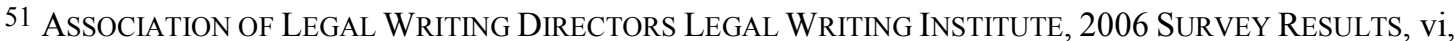
56 , available at www.alwd.org (compiling survey results on legal writing programs at 184 law schools for the 2005-2006 academic year and noting that LRW faculty members taught from as few as 15 to up to 120 first-year students but that the "average" LRW faculty member taught 44.13 first-year students). 
cognitive psychology and learning theory in an attempt to reach all of their students' varied learning styles and skill levels.

First, New Rhetoric believes that writing is a process for constructing thought. ${ }^{52}$ As opposed to traditional models of writing, which assumed that knowledge was fixed and thus focused only on the correctness or incorrectness of the finished product, ${ }^{53} \mathrm{New}$ Rhetoric holds that reading and writing are fluid and actually construct meaning. ${ }^{54}$ LRW professors using the "process" approach encourage students to write in order to satisfy their reader's needs and preferences rather than simply recording the workings of the students' verbal thought55; the process thus relies on "predicting how judges and other attorneys expect to receive information." 56 What this requires, however, is imposing a formula or structure in legal writing that conforms to the reader's expectations. ${ }^{57}$ Some

52 Linda L. Berger, Applying New Rhetoric to Legal Discourse: The Ebb and Flow of Reader and Writer, Text and Content, 49 J. Legal Educ. 155, 156-59 (1999). One scholar has described the New Rhetoric paradigm as: (1) "focus[ing] on the writing process"; (2) "rhetorically based"; (3) evaluating writing "by how well it fulfills the writer's intention and meets the audience's needs"; and (4) viewing writing as a "recursive rather than a linear process." Maxine Hairston, The Winds of Change: Thomas Kuhn and the Revolution in the Teaching of Writing, C. COMPOSITION \& COMM., Feb. 1982, at 86.

${ }^{53}$ Linda J. Berger, A Reflective Rhetorical Model: The Legal Writing Teacher as Reader and Writer, $6 \mathrm{~J}$. LEGAL WRITING: J. LEGAL WRITING INST. 57, 62 (2000); see also Hairston, supra note 2, at 78 (noting that the traditional paradigm "stresses expository writing to the virtual exclusion of all other forms, that it posits an unchanging reality which is independent of the writer and which all writers are expected to describe in the same way ... [which] makes style the most important element in writing").

${ }^{54}$ Berger, supra note 52, at 157.

55 Linda Flower, Writer-Based Prose: A Cognitive Basis for Problems in Writing, C. ENG., Sept. 1979 at 19-20.

56 Pamela Edwards \& Sheila Vance, Teaching Social Justice Through Legal Writing, 7 LEGAL Writing: J. LEGAL WRITING INST. 63, 69 (2001).

57 Godwin Phelps, supra note 2, at 1097, 1099 (noting that Flower's work in defining the New Rhetoric resulted in an understanding of the heuristic techniques of expert writers, their teachability, and their relevance for legal writers); MARY BETH BEAZLEY, A PRACTICAL GuIDE TO APPELlATE ADVOCACY 50 (2002) (describing legal writing's organizational formulas like the CREXAC model she proposes as 
scholars have argued that this approach frequently results in "regnant" lawyering, which is the opposite of the "rebellious" lawyering described above. ${ }^{58}$ Regnant lawyering focuses on "lawyering . . . in a fashion that relies on conventional remedies and institutions, and upon lawyer expertise and dominance even while seeking the client's 'best interests."'59 This regnant or traditional approach to lawyering is reinforced by LRW faculty members who attempt to, within the rubric of New Rhetoric and other learning theories, teach students to "think like a lawyer" or to "write for a lawyer" audience. 60

Regnancy is further reinforced by the role of discourse communities that some New Rhetoriticians employ to explain their students' inability to assimilate legal writing. Although New Rhetoricians generally agreed on the process approach to writing, a schism developed within the group over whether the process of constructing meaning

designed to provide readers the "information [they] need when analyzing legal issues" in the order they need it).

58 See, e.g., Edwards \& Vance, supra note 56, at 69-70 (citing Calmore, supra note 11, at 1933-34 (describing two models of providing legal services to the poor, originally described by Gerald López as "regnant" and "rebellious" lawyering: "[R]egnant lawyers tend to maintain a disassociated power over their clients, embracing the traditional lawyer-client paradigm. By contrast, "the rebellious idea of lawyering demands that lawyers (and those with whom they work) nurture sensibilities and skills compatible with a collective fight for social change."' (quoting GERALD P. LÓPEZ, REBELLIOUS LaWyering: ONE ChicANo's Vision OF PROGRESSIVE LaW PRACTICE 11-82 (1992))).

59 Paul R. Tremblay, Rebellious Lawyering, Regnant Lawyering, and Street-Level Bureaucracy, 43 HASTINGS L. J. 947, $950 \mathrm{n} .12$ (1992) (adopting and explaining the regnant/rebellious distinction originally drawn by Gerald P. López (citing Gerald P. López, Reconceiving Civil Rights Practice: Seven Weeks in the Life of a Rebellious Collaboration, 77 GEO. L. J. 1603, 1609 (1989))).

${ }^{60}$ Edwards \& Vance, supra note 56, at 69 (noting that professors who use the "process" approach to teaching legal writing try to encourage students to focus on the audience rather than the client). But Edwards and Vance's article flags the "regnancy" dangers inherent in this approach. Id. The authors encourage LRW professors to introduce social-justice issues into the LRW "before students have become thoroughly indoctrinated into traditional legal thinking" because "[b]y the end of the first year, many students will have assimilated the language of the law and will be unable or unwilling to see the biases in the law. Teaching social justice in legal writing will train students to see the social, political, and economic implications of the law and the various legal arguments they make." Id. at 70. 
occurred within the individual or the within a social-discourse community. ${ }^{61}$ Those adhering to the individual-centered view tried to "prove that a universal 'good' writing process exists and that it can be taught as a 'lockstep series of stages that students MUST go through in a predetermined and rigid fashion." 62 The outer-directed school, on the other hand, emphasized the importance of discourse communities and focused on institutionalizing processes and labeling students as "insiders or outsiders" based on whether they had acquired the requisite skill set. ${ }^{63}$ Discourse-community theorists posited that only after a student has mastered the conventions, practices and rules of the discourse, which included patterns of argument and common strategies for interpreting facts and law, could the student be deemed a good legal writer. ${ }^{64}$ Regardless, the New Rhetoricians, whether focused on the individual or the wider discourse community, created tangible processes ${ }^{65}$ and institutional models for the legal research and writing craft. And, under either approach, the student is taught to focus on what is "right" within the prescribed internal processes or "acceptable" within the discourse community. Thus, the writer's focus remains almost entirely lawyer-centered as opposed to client-

\footnotetext{
${ }^{61}$ Berger, supra note 52 at 157-59.

62 Id. at 158-59 (footnote omitted)(quoting Anne Ruggles Gere, Narratives of Composition Studies, LEGAL WRITING: J. LEGAL WRITING INST. 51, 54 (1997)).

${ }^{63}$ Id. at 159 (footnote omitted) (quoting Marilyn M. Cooper, Why Are We Talking About Discourse Communities? Or, Foundationalism Rears Its Ugly Head Once More, in WRITING AS SOCIAL ACTION 202, 204-05 (Marilyn M. Cooper \& Michael Holzman eds., 1989)).

64 Rideout \& Ramsfield, supra note 3, at 58 ; see also Godwin Phelps, supra note 2, at 1091 ("[Students] find their legal personalities by mastering a new 'tribal speech.'” (quoting KENNETH BURKE, LANGUAGE AS Symbolic Action: EsSAys On Life, Literature AND Method 53 (1966))).

${ }^{65}$ Rideout \& Ramsfield, supra note 3, at 66.
} 
centered. ${ }^{66}$ The writer is either concentrating on creating a lawyerly process within himself or satisfying the expectations of a lawyerly discourse community. These characteristics, which are hallmarks of the traditional, regnant approach to lawyering, are thus consistently reinforced by prominent LRW teaching methodologies. ${ }^{67}$

Finally, regnancy is further reinforced in the context of "expert-novice" gaps and the science underlying it, which has played an important role in LRW teaching and scholarship. ${ }^{68}$ Cognitive scientists posit that "as a learner moves from novice to expert, gaining both knowledge and experience, the learner develops patterns or frameworks called schemas to integrate and structure that knowledge and experience."69 These schemas allow experts "to detect and remember patterns in complex sets of phenomena that are essentially invisible to novices." 70 Experts, then, are more skilled problem-

${ }^{66}$ Although the practical result in many LRW courses has been to create lawyer-audience-driven writing, some LRW scholars have explored the oppressiveness that potentially results from focusing too heavily on legal discourse communities in LRW classrooms. See Lorne Sossin, Discourse Politics: Legal Research and Writing's Search for a Pedagogy of its Own, 29 NEw ENG. L. REV. 883, 899 (1995) (collecting authority and noting that legal discourse can have the effect of oppressing those marginalized outside "privileged circles of class, race and gender"); see also Kathryn M. Stanchi, Resistance is Futile: How Legal Writing Pedagogy Contributes to the Law's Marginalization of Outsider Voices, 103 Dick. L. REV. 7, 9 (1998).

${ }^{67}$ As noted above, some of these teaching choices are governed by the realities of their student population. Student writing and analytical skills vary widely within a large class. Moreover, many students value skills that can be employed in the corporate or large-firm settings in which they will initially practice. Such environments are naturally less focused on social justice and the disadvantaged client and more focused on winning within the courtroom and within the firm. Nevertheless, even if a structured, audience-centric approach satisfies the masses in a first-year classroom, dangers lurk in blindly reinforcing regnant lawyering or in failing to assess the potential regnancies inherent in a given teaching model.

${ }^{68}$ Berger, supra note 52, at 164-65 ("Like expert-novice research in general, New Rhetoric research assumes that experts do things the right way and that if only novices were to use those expert process, they would become better readers, writers, and thinkers.").

${ }^{69} \mathrm{Id}$. at 164 .

${ }^{70}$ Gary L. Blasi, What Lawyers Know: Lawyering Expertise, Cognitive Science, and the Functions of Theory, 45 J. LEGAL EDUC. 313, 344 (1995). 
solvers because "[w]hat once required conscious thought becomes for the expert automatic [and] routine." 71 Based in an understanding of this cognitive process, LRW instructors have sought to create routines, examples ${ }^{72}$ and processes for the students to follow so that the novice can follow them or perhaps "fake it" until he can gain enough experience to develop his own schemas or structures and ultimately his own expertise. ${ }^{73}$ Regnancy in this context arises because the student is taught to apply the routines, examples and processes designed to assist the lawyers, not the clients. ${ }^{74}$ Moreover, schemas by their nature are non-specific; encouraging students to substitute general routines and processes for a client's specific needs reinforces the traditional, top-down relationship between lawyer and client.

Incorporating these theories for teaching and learning not only transformed the way in which LRW has been taught over the past fifteen to twenty years, but also influenced

${ }^{71} I d$.

72 Oates, supra note 1, at 1 (advocating use of examples and their underlying structures to alleviate transfer problems in novice legal writers).

73 See Blasi, supra note 70, at 343 (stating that experts are better able to detect and remember patterns). Professor Blasi concludes that cognitive patterns may be formed, and thus the expert-novice gap may be bridged, without the accumulation of a large number of past experiences by "borrow[ing] an entire schema by means of analogy, [and] invok[ing] by analogy an 'architecture' for our mental model." Id. at 356. See also Oates, supra note 1, at 1 (concluding that in order to solve transfer problems that are acute among novice writers, LRW faculty need to provide students with a number of examples that have similar structures and to emphasize the underlying structures and possibly to present those structures in diagrammatic form).

${ }^{74}$ Some LRW faculty members have noted the dangers inherent in relying too heavily on formulas in legal writing. Judith B. Tracy, "I See and I Remember; I Do and Understand": Teaching Fundamental Structure in Legal Writing Through the Use of Samples, 21 TOURO L. REV. 297, 311-12 (2005) (encouraging use of sample memoranda which present different analyses in order to "reinforce two realities: that there is no one structure which fits all presentations; and that lawyers need to approach analysis and its written presentation considering not only their audience and purpose, but also the content, because the nature of the analysis will determine the structure of its written presentation."). The author concludes that "[r]ather than present and then qualify the utility of the formulas, teachers can provide students with instruction about structure which provides them with confidence about how to select an appropriate structure on their own and recognizes the need for flexibility." Id. at 313. 
how teachers evaluate and interact with their students and how students internalize teacher comments and learn from their own writing. In a discipline that now emphasizes patterns, routines, conventions and traditional structures to explain a process-based approach to writing, a teacher's comments and students' grades are necessarily heavily tied to the students' ability to internalize and then apply these formulae and structures. Comments on drafts are often by necessity more formulaic, prescriptive and rigid, as LRW teachers attempt to corral the varied writing styles of their many students and to insert them into an acceptable discourse, one that future employers will recognize as their own and consider "good" legal writing. ${ }^{75}$ Thus, evaluation is tied more to satisfying the legal reader than to meeting their client's specific needs because students are graded based on their ability to apply the formula and to anticipate and deliver their arguments in a legal-reader friendly way. ${ }^{76}$ And, to the extent that reflection on the writing and its process occurs, it is rarely backwards-looking. Rather than assessing past writing experiences, more often than not reflection is confined to the ongoing process of revision within a particular draft or in anticipation of a future assignment. ${ }^{77}$

To summarize, clinics and their faculty can be broadly defined by the following characteristics: (1) rooted in public service but with increasing focus on educating

75 Jane Kent Gionfriddo, The "Reasonable Zone of Right Answers": Analytical Feedback on Student Writing, 40 GONZ. L. REV. 427, 430-37 (2005).

${ }^{76} \mathrm{Id}$. Gionfriddo notes that "[a]lthough each student has a unique method of thinking and composing, certain prescribed methodologies must be followed when working with legal analysis." Id. at 436. Thus, “[w] hen commenting on students' work, teachers need to provide feedback as expert legal thinkers and writers. As educators, they must assist the student to understand the process of crafting legal analysis and using it to solve problems. At the same time, teachers must play the role of attorneys and judges who are interested in the results of that process as they appear 'within the four corners of the document." Id. (footnotes omitted).

${ }^{77}$ Berger, supra note 53, at 59 (noting opportunities for teacher and student reflection during the writing process but not after it). 
students through this process; (2) embracing progressive, client-centered lawyering as the model; (3) adopting teaching methodologies that are experiential, reflective and noninterventionist; and (4) under a constant tension between the need to educate the student through experience and the clinical faculty's ethical duty to ensure that the client is receiving adequate representation. ${ }^{78}$ LRW programs, on the other hand, are broadly characterized by: (1) pedagogy steeped in New Rhetoric composition theory, socialconstructive discourse theory and cognitive psychology; (2) resulting teaching methodologies that emphasize writing to an institutionalized legal audience, applying set writing processes, and operating within an established legal discourse community; and (3) teaching styles that must by their very nature be directive. ${ }^{79}$ This dichotomy, between the "rebellious" clinician and the "regnant" LRW professor, between the need to establish the structures and institutions before challenging and deconstructing them as progressive lawyers, ${ }^{80}$ and between teaching styles dictated by the development of the discipline that are, on the clinical side, mostly bottom-up and backwards-looking to, on the LRW spectrum, top-down and forward-looking, create the most fundamental barriers to understanding, collaboration and seamless teaching.

\footnotetext{
78 See supra text accompanying notes $20-42$.

${ }^{79}$ See supra text accompanying notes $43-77$.

80 Although beyond the scope of this article, one might ask whether such an ordering is necessary. That is, whether a student needs to know the existing structures in order to question and ultimately deconstruct them in other contexts. Regardless, the thrust of this article is not that that paradigms and formulae are ineffective or even detrimental, but rather that LRW faculty members should not encourage unquestioning reliance on a structures and traditions that might later impede a student's ability to lawyer in other, different discourses and contexts. And, similarly, clinicians should learn the existing structures in order to use them when appropriate and to deconstruct them when it is not appropriate.
} 


\section{Other Practical and Perceived Barriers}

In addition to the substantial barriers presented by the differences between the disciplines and each one's approaches to teaching, other practical barriers to collaboration in instruction exist: (1) competing demands on the faculty; and (2) physical separation, differing status, lack of communication and the reality of how little collaboration presently occurs; and (3) the lack of knowledge about the other's teaching and scholarship.

First, clinicians and LRW faculty members are both extremely busy, but in very different ways. Although clinicians generally supervise fewer students who are often more-experienced second and third-year students, they have a heavy caseload, student supervision, courtroom and teaching responsibilities as well as scholarship interests and other law school commitments. ${ }^{81}$ LRW faculty are equally busy with scholarship and law-school service commitments, but they also have much larger classes, which average 45 students per semester but run as high as 120 per semester, and overwhelming grading

${ }^{81}$ Kimberly E. O'Leary, Evaluating Clinical Law Teaching_Suggestions for Law Professors Who Have Never Used the Clinical Teaching Method, 29 N. KY. L. REV. 491, 511-12 (2002) (noting clinicians' necessary service to the practicing bar, university committees, and national lawyering organizations as a part of their job and describing the clinician's typical week as consisting of eight hours of one-on-one supervision meetings with students; about three hours of classroom instruction; between one and three court appearances; between two and twenty hours of additional student supervision on casework; between one and three hours of law school committee meetings; between one and three lunch meetings with lawyers, judges, community groups, task forces, and the like; and time devoted to numerous small interruptions by students, clients, and colleagues.); Stephen Wizner \& Jane Aiken, Teaching and Doing: The Role of Law School Clinics in Enhancing Access to Justice, 73 FORDHAM L. REV. 997, 1003-04 (2004) (contrasting the role of the supervising attorney in a community legal services office and that of the clinical professor and describing the expanded responsibilities of the latter role as consisting of "teaching classes, writing articles, serving on committees, attending conferences" in addition to direct student supervision). 
and commenting demands. ${ }^{82}$ First-year law students are particularly demanding and

LRW faculty members also spend a tremendous amount of time developing multiple new

writing problems each year. ${ }^{83}$ And while both clinicians and LRW faculty members

devote substantial time to teaching, clinicians teach a wider variety of skills and

substantive law, while LRW faculty members provide more in-depth coverage to the

nuances of writing, research and legal analysis. ${ }^{84}$ To the extent that a clinician even

touches upon writing during the clinic's classroom component, that instruction

necessarily must be limited in order to accommodate the other topics that arise in a

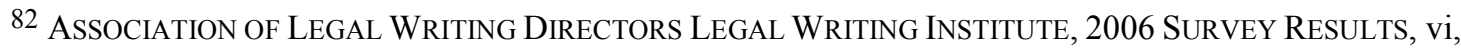
available at www.alwd.org [hereinafter 2006 SURVEY RESULTS] (compiling survey results on legal writing programs at 184 law schools for the 2005-2006 academic year). The survey reports that LRW faculty members spend an average of 3.73 hours a week on in-class instruction; assign an average of 3.6 minor written assignments and 3.24 major writing assignments; read, evaluate and critique an average of 1,585 pages of student written work; conduct an average of 49.39 hours worth of student conferences; spend an average of 34.47 hours designing and preparing major research and writing assignments; and devote an average of 65.1 additional hours to preparing for class instruction. $I d$. LRW faculty members also report additional demands on their time: $80 \%$ serve on a faculty committees, and LRW faculty members at nearly one third of the reporting LRW programs are required, expected or encouraged to produce written scholarship. Id. at vi - vii. See also Maureen F. Fitzgerald, What's Wrong with Legal Research and Writing? Problems and Solutions, 88 LAW. LIBR. J. 247, 250 (1996) (finding that the majority of LRW programs assign between 50 and 150 students to each LRW instructor).

${ }^{83}$ See Grant, supra note 44, at 391(noting that, because of the extensive interaction they have with their students, LRW professors inevitably spend many hours "nurturing" their students); Melissa MarlowShafer, Student Evaluation of Teacher Performance and the "Legal Writing Pathology:" Diagnosis Confirmed, 5 N.Y. CITY L. REV. 115, 129 (2002) (noting the added difficulty of teaching LRW to firstyear students because of the anxiety and hostility LRW courses arouse); Joseph M. Williams, On the Maturing of Legal Writers: Two Models of Growth and Development, 1 LEGAL WRITING: J. LEGAL WRITING INST. 1, 10 (1991) (describing the LRW instructor's role in "socializing" first-year students and helping them adapt the critical thinking skills they developed in undergraduate courses to the law and legal writing); Ellie Margolis \& Susan L. DeJarnatt, Moving Beyond Product to Process: Building a Better LRW Program, 46 SANTA CLARA L. REV. 93, 131 (2005) ("One of the biggest challenges of teaching LRW is problem design."); Ian Gallacher, Forty-Two: The Hitchhiker's Guide to Teaching Legal Research to the Google Generation, 39 AKRON L. REV. 151, 168 (2006) (discussing the challenges of teaching legal research to students who have not yet mastered the first-year law curriculum and admitting that, though an overstatement, the process is somewhat like "trying to teach the wrong people the wrong material at the wrong time"' (quoting Robert C. Berring \& Kathleen Vanden Heuvel, Legal Research: Should Students Learn It or Wing It?, 81 LAW LIBR. J. 431, 441 (1989))).

${ }^{84}$ See supra text accompanying notes $20-42$ and $43-77$. 
clinical setting such as social-justice issues, ethical and client-based considerations, issues of substantive law specific to the clinical practice, and other practice skills. Perhaps, then, the busy clinician has very little incentive to collaborate with LRW faculty members given the smaller amount of time spent on writing in her course. And, LRW faculty members who are swamped with the demands of so many students have little time to expand their focus beyond their first-year instruction. In summary, true collaboration requires time and work, both of which are in short supply among clinicians and LRW; thus, the reality of the day-to-day courseloads presents a barrier to collaboration.

Even if these differences in teaching and courseloads could be bridged for a more collaborative atmosphere, they remain divisive due to a combination of other factors that impede collaboration and seamless instruction. Specifically, the physical separation between clinical and LRW faculty, differing status issues, lack of communication and the reality of how little collaboration presently occurs also contributes to the "clinical divide." At many law schools, including Northwestern, LRW faculty and clinical faculty are physically separate, thus impeding routine communication that could foster collaboration among departments. ${ }^{85}$ Similarly, although at many schools LRW and clinical faculty are addressing status, pay and tenure issues, each department may be fighting for different goals and so the departments often are not unified on this front. ${ }^{86}$

85 Grant, supra note 44, at $392 \mathrm{n} .197$ ("LRW offices that are tucked away in corners force LRW professors to 'remain separated physically from ongoing intellectually-sustaining interactions with the 'real' faculty." (quoting Maureen J. Arrigo, Hierarchy Maintained: Status and Gender Issues in Legal Writing Programs, 70 TEMP. L. REV. 117, 150 (1997))).

86 Compare 2006 SURVEY RESULTS, supra note 82 at v (reporting that faculty in the majority of LRW programs are on short-term contracts, with 54 on one-year contracts, 20 on two-year contracts, and 53 on contracts of 3 or more years; 28 have ABA Standard 405(c) status, 10 are on ABA Standard 405(c) status track; and 25 are on tenure track) with David F. Chavkin, Spinning Straw into Gold: Exploring the Legacy of Bellow and Moulton, 10 CLINICAL L. REV. 245, 273 n.94 (2003) (reporting that, 
Due to these factors as well as the fact that faculty within both departments are often extremely busy, communication between them is often lacking. Finally, even in places where some collaboration exists, it is minimal and informal. Based on information collected by a national survey of legal writing programs and legal writing directors by the Legal Writing Institute's Committee on Cooperation between Clinic, Pro Bono, and Legal Writing Programs, there is but a smattering of actual collaboration going on between clinics and legal writing programs. ${ }^{87}$ For example, of survey respondents, only ten to twelve clinical faculty members talk to and/or assist LRW classes and a similar number of LRW faculty members reciprocate in the clinics. ${ }^{88}$ Notably many of these clinical faculty members are also LRW faculty members who have joint appointments

according to statistics compiled by the AALS Section on Clinical Legal Education and the Clinical Legal Education Association, 51\% of reporting clinical faculty were tenured or on tenure track, while only $25 \%$ were on short-term contracts as of 2001). See also Wizner \& Aiken, supra note 81 , at 9991002 (describing clinicians' initial struggle to obtain legitimacy and job security as well as their more recent "assimilation" into the faculty and their ongoing "aspiration for faculty status"); Marina Angel, The Modern University and Its Law School: Hierarchical, Bureaucratic Structures Replace Coarchical, Collegial Ones; Women Disappear from Tenure Track and Reemerge as Caregivers: Tenure Disappears or Becomes Unrecognizable, 38 AKRON L. REV. 789, 797 nn. 53-54 (2005) (contrasting the security requirements for clinical and LRW faculty established by the ABA accreditation standards and noting that the former must be afforded "'a form of security of position reasonably similar to tenure" while the latter must only receive " such security of position and other rights and privileges of faculty membership as may be necessary to (1) attract and retain a faculty that is well qualified to provide legal writing instruction....and (2) safeguard academic freedom."' (quoting AMERICAN BAR ASSOCIATION, SECTION OF LEGAL EDUCATION AND ADMISSIONS TO THE BAR, 2005-06 ABA STANDARDS FOR APPROVAL OF LAW SCHOOLS ACCREDITATION STANDARDS § 405(c) - (d), available at http://www.abanet.org/legaled/ standards/chapter4.html)).

${ }^{87}$ See AALS Handout, supra note 10 (on file with author).

${ }^{88}$ See AALS Handout, supra note 10 (on file with author) (observing that nearly all of the interaction is informal; some of the "individual efforts" include "promot[ing] the clinic to 1-Ls" and having "clinical faculty serve as judges for oral arguments." LRW faculty's contribution to clinics, although somewhat more formalized, also is fairly compartmentalized. For example, respondents reported giving presentations to clinics on: "Top Ten Suggestions for Writing Persuasive Motions"; "writing under pressure, client letters, writing for a particular audience, motion practice"; "professional letters, giving presentations, memos to file"; "cover letters, resumes, writing samples"; "email, drafting analogies \& distinctions"; "storytelling and persuasion"; and "citation; drafting."). 
with the clinic. ${ }^{89}$ Less than twenty schools reported any kind of "informal collaboration" among departments that included activities such as "[discussing or working] to change status" or "sit[ting] on committees together." 90 Finally, only a few schools have direct crossover between their LRW department and their clinics with, for example, crossappointments between departments or curricular redesign to merge clinical and LRW skills into a single course. ${ }^{91}$ For the most part, then, LRW faculty members and clinicians simply do not know what each other are doing in any real and specific way, which obviously impacts their ability to identify potential avenues of collaboration.

Thus, although both LRW faculty members and clinicians consider themselves teachers and scholars, they came from different places, they teach based on different assumptions, and they have different demands on their time and energy, so they ultimately focus their teaching differently. And each department has very little idea of how the other one teaches. If continuity and collaboration between departments in order to provide a more seamless education for the students is a goal, then schools and faculty must acknowledge and address these differences and work to create increased understanding and some common teaching ground to effectuate this goal.

89 See AALS Handout, supra note 10 (on file with author).

90 See AALS Handout, supra note 10 (on file with author) (noting numbers of "LRW faculty and clinicians try to stay "on the same page"" (4); physical "proximity promotes exchange/collaboration" (4); "LRW faculty promote clinic, externships, and programs" (4); "LRW faculty as informal in-house writing/skills experts for other faculty" (1); Assistance with moot court" (4); "joint scholarship workshop" (1); "hold brown-bad workshops on teaching writing, practice skills" (3); "discuss teaching" (2)).

${ }^{91}$ See AALS Handout, supra note 10 (on file with author) (indicating that only six LRW professors teach in the clinics, of which the author is one; only three clinical professors teach in LRW and some have explicit cross-appointments. Three schools reported curricular redesign to merge clinical and LRW skills into one course and two schools reported adding hybrid clinical-LRW courses, of which the author's was one). 


\section{Overcoming the Barriers}

Recognizing these potential barriers, particularly the fundamental barriers created by the diverging development of the disciplines and teaching styles, is the first step to surmounting them. Effective collaboration between LRW and clinical faculty calls for an understanding of the ways each discipline can supplement and enrich the other. Only with this understanding will LRW and clinical faculty be able to undertake the next and the most critical step: integrating aspects of each other's teaching methodologies in their courses. ${ }^{92}$ If clinicians recognized that teaching paradigms exist in LRW and became more familiar with this terminology as well as the fundamental tenets guiding first-year writing instruction, such as New Rhetoric, social constructivism, and other learning theories, they would be in a better position to understand their students' baseline writing abilities and to teach from that starting point according to familiar processes and models and a pattern of consistent feedback. ${ }^{93}$ Furthermore, if clinicians recognized the fact that second-year students are still very much beginning writers and fall prey to novice mistakes, they could more easily anticipate and identify those pitfalls and guide the

92 Indeed, this dialogue has already begun. At the recent 2006 AALS Conference on Clinical Legal Education the theme was collaboration. At the conference one session was devoted to "Collaboration Across Law School Programs" and specifically discussed "the rewards and challenges of collaboration between clinics and legal writing programs." See AALS Handout, supra note 10 (on file with author). During this session, participants discussed the skills that could be transferred between LRW programs and clinical programs. For example, LRW programs could benefit from incorporating concepts of professional responsibility, reflective learning and access to justice issues, each of which plays a central role in clinical teaching. Conversely, core LRW tenets such as new rhetorical composition theory, social constructionist theories and other learning theories, if integrated into clinical methodology could enhance students' clinical experience.

93 See Campbell, supra note 1, at 658-62 (noting that clinicians should "incorporate insights from some legal research and writing professors, who in turn, apply many of the ideas of the so-called 'new rhetoricians"'). 
students around them. ${ }^{94}$ Consistency in terminology and approach is even more important when clinicians recognize that students entering a clinical setting are entering a new subset of legal discourse with different demands. A discourse community is an entity that "considers social roles, group purposes, communal organization, ideology and finally theories of culture."95 First-year LRW programs strive to introduce this new legal discourse community, its language and conventions, and thus create each student's legal writing persona, in a structured and controlled environment. 96 The clinical community, even within the narrow task of legal writing, introduces new goals, a new language and a new culture, one that includes real clients, cases with complex social issues and the task of honing the student's professional persona. ${ }^{97}$ Such a shift can be disorienting for a law student who is accustomed to writing in a much more controlled environment and with a defined terminology. Thus, recognizing these differences and integrating discourse theory into clinical teaching in this way also would help explain why students' writing

\footnotetext{
94 See Carol McCrehan Parker, Writing Throughout the Curriculum: Why Law Schools Need it and How to Achieve it, 76 NEB. L. REV. 561, 563 (1997) ("Neither a single 'rigorous writing experience nor a firstyear legal writing class is sufficient to provide basic competence in written communication.") .

95 Marie A. Monahan, Towards a Theory of Assimilating Law Students into the Culture of the Legal Profession, 51 CATH. U. LAW. REV. 215, 232-33 (2001). Thus, the legal discourse community is composed of subsets of mini-communities that focus more narrowly on their own purposes, ideology and culture. See Susan L. DeJarnatt, Law Talk: Speaking, Writing, and Entering the Discourse of Law, 40 DUQ. L. REV. 489, 491-92 (2002) (noting that legal discourse community can be broken into subcommunities such as the law-school community, which focuses on teaching students to become literate in both the academic and practice-based legal communities). Just as the law school is one subcommunity within the wider legal discourse community with its own norms, goals, and practices, so too are individual departments within a law school subsets of the legal discourse community.

96 See Monahan supra note 95, at 234.

${ }^{97}$ Id. at $234-35$.
} 
expertise initially dips and would incent clinicians to take time to orient newcomers to this discourse in the hopes that the students would catch up more quickly. 98

LRW faculty members could begin to consider whether the emphasis on traditional paradigms and institutions in their teaching adversely impacts a student's ability to flexibly approach new problems and scenarios and whether LRW instruction should be adjusted to mitigate this effect. ${ }^{99}$ LRW faculty members could further benefit from the clinics' exploration of adult-learning pedagogy in the context of experiential learning opportunities and could consider whether integrating aspects of this learning style into first-year courses could improve student performance. ${ }^{100}$ LRW faculty members could start to emphasize that a client may have needs beyond simply submitting a winning brief and that students should consider those competing, and sometimes conflicting, interests so that when they first encounter them in clinical practice they are better prepared to handle them. And although many LRW faculty members emphasize the importance of reflection during the writing process, ${ }^{101}$ increased reflection at the end of the process that is independent of the revising and grading process would be a useful tool for students who seek to improve their writing. Finally, once students have adopted the basic

98 See Andrea McArdle, Teaching Writing in Clinical, Lawyering, and Legal Writing Courses: Negotiating Professional and Personal Voice, 12 CLINICAL L. REV. 501, 501-02 (2006) (noting the importance of navigating professional and personal voice and clinicians' and legal writing teachers' roles in "acculturating law students to the conventions of practice-based writing."); Rideout \& Ramsfield, supra note 3 , at 75-76.

${ }^{99}$ See McArdle, supra note 98, at 501-02.

100 As noted above, some already advocate for integrating clinical experiences into the first-year LRW curriculum. See Millemann \& Schwinn, supra note 1.

101 See, e.g., Berger, supra note 52, at 165 (describing expert legal writers' use of self-reflection, concluding that legal writing teachers should "focus on helping students reflect on and respond to what they read and write," and suggesting various ways to do so). 
paradigms that form the foundation of most legal writing, recognizing and rewarding the variations in students' writing that can ultimately persuade a legal reader and, thus, fulfill her expectations, can begin to hand control back to the students in ways that foster creativity and cultivate their own narrative voices. ${ }^{102}$

Remedying the practical barriers also will have spillover benefits to students and faculty within these disciplines. Put simply, clinicians and LRW faculty members should interact more because doing so will help them and their students. They should work together to identify areas where bridges between the first-year LRW course and upperlevel clinical courses can be built. LRW professors should solicit ripe legal topics for their memo and brief problems from clinicians. Clinicians should work with LRW professors to learn the fundamental paradigms and language used to teach those first-year skills so they can continue them in their own courses. And LRW professors should be guest lecturers on advanced writing techniques. The departments could work together to understand and ultimately combat prevailing status, scholarship, and professionaldevelopment issues within their law school. Doing so might also identify ways to streamline some of the commitments that create onerous burdens on professors' time. ${ }^{103}$

102 Terrill Pollman, Building a Tower of Babel or Building a Discipline? Talking About Legal Writing, 85 MARQ. L. REV. 887, 892 (2002) (noting "[t]he greatest opportunity that the study of law offers 'is not that one can learn to manipulate forms, but that one can acquire a voice of one's own, as a lawyer and as a mind; not a bureaucratic voice but a real voice."') (quoting JAMES BOYD WHITE, FROM EXPECTATION TO EXPERIENCE: ESSAYS ON LAW AND LEGAL EDUCATION 25-26 (1999)).

103 The potential challenges and downsides to this approach are mainly practical. Instituting these changes will require each department to learn the other's best practices and to find time to communicate with each other. 
V. Crossing the "Clinical Divide": One Teacher's Attempt to Bridge the Gap

I encountered many of these barriers as I designed and taught a new federal appellate clinic at Northwestern. Having taught LRW for the past six years, both fulltime and as an adjunct, I was steeped in the theory and pedagogy underlying the LRW discipline. I had, however, always been interested in clinical law and the role it played in serving the public interest while simultaneously educating students. I became increasingly interested in teaching a clinical class that would also incorporate advanced writing instruction. As I transitioned from a LRW professor to a clinical professor of advanced legal writing, I encountered many of the very barriers discussed above.

\section{A. The Preliminary Design}

In my attempts to get final approval for the course and in order to create a design template, I accepted a pro bono appointment with the Seventh Circuit to represent a criminal defendant on appeal. This experience directly influenced specific design choices in the new clinic. I recruited several talented former students who were willing to work on the case for no course credit and for little or no compensation; they were interested in the experience and in participating in the "real" practice of law. I asked them to commit to researching and writing discrete portions of the brief but little else because I did not want to take advantage of their goodwill and because they were otherwise extremely busy with their courses, law reviews and other extracurriculars. I too was extremely busy as I took on the appeal while teaching a full first-year LRW section. Thus, choices that I made during this case and in my initial design of the clinical course were impacted somewhat by these time constraints. 
I wrote to my client, introduced myself and solicited feedback from him regarding possible issues on appeal. At the same time, we investigated the record and tried to identify the best possible issues on appeal. The students were in charge of researching the proposed issues and assessing their success. We met in weekly or bi-weekly meetings to discuss our progress on the case. Our working model, however, was patterned after traditional law-firm practice with me acting as the senior partner and my students as associates reporting back to me with their research. ${ }^{104}$ The client wrote back with his suggested issues; after investigating them, however, we concluded that none had a serious chance of prevailing. I wrote him and explained why we would not be raising his proposed issues on appeal and explained the three issues we would be raising on his behalf. He responded by denying my request to permit the students to present oral argument and by filing a pro se motion to supplement our brief on appeal. I was frustrated by this experience, especially in the wake of the hundreds of hours we had spent preparing his appeal, and I shared that frustration with the students, who then had trouble sympathizing with our client.

The students' research efforts were quite good; in fact our primary issue on appeal was one that a student identified. Their writing was on par with second-year law student prose and it ultimately required substantial revision. Because of the overriding time constraints on both sides I could not give them the kind of feedback over multiple drafts that I wanted and they deserved. Instead, I co-opted their submissions after heavily editing and reorganizing them. We never found time to discuss their writing or ways to

104 I would have preferred to have given them more authority and autonomy at this point as well as increased responsibility for the day-to-day management of the case. But because of the limited time and commitment I had asked of them, I could not delegate increased work or responsibility to them. 
improve it. We did pull together for one late night to finalize the brief and it was this teamwork, along with our earlier collaborative group brainstorming meetings, that I found most satisfying in this process. By the time the reply brief and oral argument rolled around, however, the students were well into finals and their summer jobs, so I was essentially on my own for the second half of the appeal.

In the wake of this experience, as well as my experience as a LRW teacher, I set out to design the new federal appellate clinic, which I envisioned as a distinct hybrid course. I was certain of the aspects of my existing LRW pedagogy that I wanted to incorporate, but less certain about my role as clinician and supervisor. I knew that I wanted to create a rich classroom component with a constant, overarching emphasis on the process of writing, revision and persuasion in the appellate context. I wanted to create an in-depth writing component and other broad exposure to substantive criminal law and guiding clinical principles such as client-centered advocacy, social-justice issues, ethical concerns and collaborative, reflective learning. But I felt I could accomplish these goals within a traditional law-firm practice model where the students acted as associates and I acted as the partner. I remained attached to the idea that we could craft a perfect, professional brief under a traditional law-firm model while still giving the students a valuable clinical experience. I also was particularly concerned with creating and following a precise timeline since I would be ultimately responsible for filing eight appellate briefs in a very short amount of time; to that end, I sent up a fairly rigid drafting structure within the context of the fall syllabus. Although the topics I chose for each week's class reflected a concerted effort to create a hybrid clinical-LRW course, I 
initially intended to present many of those topics in the traditional "lecture-and-exercise" mode that I had used in my first-year course. ${ }^{105}$

\section{B. The Revised Design}

To begin the process of crossing over from a LRW professor to a clinical professor, I attended the 2006 AALS Conference on clinical education. It was at this conference that I was first struck by the notable differences between the clinical field and the LRW field, even in clinics that focused primarily on writing. That is, although the professors were troubled by students' writing and the ultimate work product submitted to the court, they were equally concerned with their role as supervisors, editors, teachers and lawyers. ${ }^{106}$ They struggled with their dualistic roles as teachers and lawyers and were concerned about students' failure to follow through on their work and their own overediting or taking control of the students' briefs in the midnight hour. As for teaching, I was surprised to learn that even in writing clinics, teaching of writing was given minimal attention. Clinical writing professors spent class time teaching other important concepts

105 I originally intended to take four to five appeals over the course of the academic year. I planned on asking the Seventh Circuit for a briefing schedule that called for three opening briefs to be filed in the fall semester and the remaining two to be filed in the spring semester, with students potentially working on more than one appeal over the course of the academic year. Because each of the students was going to be on a different timeline, the classes initially were not particularly case-driven, but rather focused more generally on the topic of the day and included more lecture or top-down teaching by me. The original ordering of the course topics (by week) over a fourteen-week semester included: (1) introductions; (2) digesting the record, jurisdiction and standard of review, and a research refresher; (3) selecting issues on appeal, formulating a timeline and learning the rules of appellate procedure; (4) introduction to the practice of criminal law; (5) in-class edits and discussion of research and writing roadblocks; (6) advanced writing and persuasion techniques; (6) group edits; (7) drafting statements of facts; (8) revision and legal writing style; (9) drafting the remaining brief sections; (10) client sensitivity and access to justice issues; (11) group editing and cite checking; (12) preparation of brief one; (13) preparation of brief two; and (14) preparation of brief three.

106 AALS Conference on Clinical Legal Education, notes from working group (April 30-May 1, 2006) (on file with author). 
such as translating the system to the client and the client to the system, use of judgment, compassion and understanding, and instilling a more forward-looking vision into their students. ${ }^{107}$ Class time was spent discussing the clinics' cases and the client, and the cases were very much in the students' hands. Clinicians were simply too busy with their caseload and their competing teaching goals to devote much explicit classtime to reinforcing writing skills.

I learned from these clinicians that I needed to make some changes in my teaching in order for my new clinic to work. Specifically, I needed to incorporate more of a clientcentered and experiential-teaching approach into the course. I needed to remain studentfocused and teaching-focused, but not to the exclusion of my clients' interests, which meant that I needed to be less paternalistic with respect to decision-making in the case. Based on my experience with the ad hoc appeal that I had just finished, I knew that I wanted to be more client-centric by striking more of a balance between providing a good educational experience to my students and my obligation to my client. In addition to voicing frustration with a client, I also needed to work with the students to empathize with the client and his or her point of view.

I also needed to be less paternalistic with respect to the students. Unlike my firstyear LRW course, I felt that I should spend less class time instructing and instead let the students teach themselves and each other during planned, structured and case-related exercises. I had to be prepared to give up control of the case to the students, even if that meant the brief was imperfect. Although the students needed guidance in formulating

${ }^{107} I d$. 
and structuring arguments, my role was to assist each one in finding his or her own writing style and voice. My editing had to become more facilitative and less directive or dictatorial because I had to recognize that outside of the first-year LRW classroom, there simply is not one "correct" way to craft an argument. I needed to allow for multiple drafts so that the students had sufficient time to work through the writing and revision process on their own but still have access to me as a resource for questions and guidance when needed. And, I needed to allow the students flexibility to control their own individual pacing in working toward filing deadlines, rather than impose rigid deadlines short of the brief-filing deadline because of my apprehension about filing eight appellate briefs in a very short period. In short, I needed to become less regnant in both my lawyering and my teaching.

I did, however, keep several important concepts from LRW. First, I designed the syllabus with an eye towards emphasizing writing as a multi-step, recursive process. Each week's classroom topic was chosen to slowly unfold and emphasize the process of writing. Class sessions were structured to give the students practice with the various stages of the process of crafting an appellate brief and legal argument, but each of the inclass exercises were based on their actual cases. Also, recognizing that this writing clinic would be a new discourse for most of the students, I tried to ease the students' acculturation into the discourse by providing background procedural and substantive information (including guest speakers) frequently but in small doses throughout the early weeks of the course. Finally, recognizing that even third-year law students are still novice writers, I planned to exploit this fact and address it head-on in early classes so that the students could better understand their writing weaknesses and where they originated 
in order to ease their frustration once they delved into the messy and complicated task of drafting a criminal appellate brief.

As a result, I revamped the syllabus with an eye towards creating a collaborative, student-directed, and client-centered classroom component. Topically, I kept all many of the original topics, but emphasized lectures and "direct" teaching less and their cases and own writing more. 108 The revised course was founded on seven guiding principles. First, I felt it was extremely important for the students to progress on the same schedule and to be addressing the same issues in the early part of the semester so that class time could be collaborative, student-driven, and case-based. I revised the briefing schedule for our cases to accommodate this approach. Second, I wanted classtime primarily to be student-driven. I reduced lecture to a minimum and instead devised classroom

108 After reflection, I decided to take only four appeals for eight students and take them all at the beginning of the year. Doing so permitted the students to work in lock-step, at least for the first eight or ten weeks of the semester, on discrete portions of their brief that could then be integrated into classroom discussion. I revised the syllabus to create collaborative, interactive and student-driven class time. I also enlarged the class time devoted to the writing process and shortened discussion of substantive and nuts and bolts topics. Under the revised syllabus, the fourteen week semester included the following topics: (1) introductions: getting to know each other; getting to know your client; getting to know your reader; and getting to know yourself as a writer; (2) getting and digesting the record; the research process and creating research plans; jurisdiction and standard of review; (3) the writing process, circulating digests, brainstorming issues; (4) introduction to the practice of criminal law (guest speaker), framing issues and identifying your theme/story; (5) Presentations on final issues; circulate research plan and large-scale outlines; peer review and discussion; (6) Persuasion I: persuasive brief creation (organization/presentation; framing of issues \& arguments; creating persuasive rules; persuasive use of equity and policy), peer edits; (7) Persuasion II: Persuasion through use of authority and dealing with contrary arguments, prepare group presentations on four techniques; (8) Persuasion III: Persuasion through writing style and advanced persuasion techniques, bring in draft for peer review that incorporates one advanced technique; (9) storytelling and the facts of your case; (10) prepare presentation on your assigned brief component and incorporate applicable federal and local rules/requirements where applicable; (11) four rounds of focused peer editing; (12) editing and client-sensitivity; (13) preparation week for brief one, which is due in December; (14) preparation week for brief two, which is due in early January. 
assignments and exercises that allowed the students to collaborate with and teach each other and to brainstorm on their writing projects. Third, the students needed to make a connection with their clients and to learn their client's story. To that end, the students would go meet the client and focus on creating a theme and story for their client that could be interwoven with the briefing of the legal issues. The students also needed to learn how to communicate and compromise with a client who might insist on a different approach for the brief. Fourth, the course retained a structured emphasis on writing through discrete, case-based assignments and targeted editing and revising throughout the semester. Fifth, I wanted to ensure that the students retained a sense of pride and ownership over their case and learned professionalism. To that end, I envisioned a collaborative process not only with the other students but also with me. I would work with the students to formulate the plan on appeal but would refrain from dictating issues or results. Sixth and relatedly, my role as supervisor would focus on facilitating discussion and brainstorming as well as reviewing the multiple drafts the students submitted. Finally, I created what I called "crunch weeks" for the week leading up to a filing deadline where all of the students in the clinic would be expected to pitch in to edit, cite-check, proofread and finalize a brief. In the second semester, this collaboration and assistance would continue with students preparing bench memoranda and oral argument moot courts for each other. At the end of the process, I felt that I had struck a nice balance between the clinical methodology and a LRW approach to advanced legal writing. I had moved away, at least in part, from regnant, top-down teaching but also tried to reinforce the writing tenets that govern most LRW pedagogy. 
VI. Conclusion

Although barriers do exist that may impede collaboration across law school departments, those barriers can be addressed and overcome with a conscientious commitment to do so. The first step is recognizing the barriers inherent in each department's methodologies. The next step is for clinics and LRW departments to adopt the other's best approaches in order to provide continuity to students' writing and ultimately improve their writing. If clinicians learn the language and pedagogy underlying LRW and if LRW faculty become more aware of instilling potential regnancies that are at odds with clinical practice, then perhaps the two disciplines can bridge the divide and pave the way for increased collaboration and seamless instruction to our students. 